\title{
PKM PENGEMBANGAN TEKNOLOGI PRODUKSI DAN PEMASARAN BERBASIS DIGITAL PADA KELOMPOK PENGHASIL PRODUK FURNITURE DI KELURAHAN DAWUHAN SITUBONDO
}

\author{
Randika Fandiyanto \\ Email :dika_face31@yahoo.co.id \\ Universitas Abdurachman Saleh Situbondo
}

\begin{abstract}
Abstrak: Kabupaten Situbondo merupakan salah satu daerah yang ada di Provinsi Jawa Timur. Situbondo juga merupakan salah satu sentra UMKM penghasil produk-produk kerajinan (handycraft). Tinginya persaingan membuat para pelaku bisnis UMKM ini dituntut untuk selallu melakukan inovasi-inovasi serta perlu adanya strategi-strategi khusus yang bisa menciptakan kekuatan bersaing. Mitra terdiri dari dua yaitu Kelompok Usaha Furniture dan Penghasil Kayu Gmelina. Permasalahan yang ditemukan dan solusi yang ditawarkan melalui program kemitraan masyarakat (PKM) ini yaitu, Pertama minimnya pengetahuan akan prinsip efisiensi dan efektifitas dalam produksi sebuah produk, Teknologi yang pemegang peranan penting untuk menciptakan produk berkualitas dan bernilai ekonomi tinggi. Kedua kurangnya pemahaman dunia daring/online. Ketidakmampuan memahami dunia tekhnology dapat menghambat kemajuan usaha. Masyarakat cenderung memasarkan produk dengan bekerjasama pada pengepul produk seperti di Bali, menyebabkan nilai jual produk menjadi rendah dan berdampak pada keuntungan yang diperoleh. Ketiga Kurangnya motivasi untuk membangun industri ke jenjang yang lebih maju. Hal ini diakibatkan tidak memahami manfaat dunia teknologi yang bisa merubah perjalanan bisnis menjadi lebih cepat dan mampu bersaing secara nasional maupun internasional. Program ini merupakan pembinaan dalam bentuk perbaruan metode produksi dan pemasaran dengan langkah yang lebih efektif dan efisien. Minimnya pengetahuan para pelaku usaha untuk bisa menghasilkan produk berkualitas. Pembinaan ini dilakukan dengan melalui metode Penerapan Mesin Produksi, Pelatihan Teknis Pemotongan, Penghalusan, dan Finishing, Pelatihan Pemasaran Berbasis Digital dan Pendampingan akhir. Luaran yang dihasilkan dari kegiatan ini adalah Menumbuhkan Jiwa wirausahaan yang maju dan berinovatif, Meningkatkan pengetahuan pentingnya tekhnologi dalam usaha pengolahan kayu menjadi produk furniture, Meningkatkan pengetahuan pemasaran online dengan media ecommerce sehingga meningkatkan pangsa pasar produknya, Meningkatkan kesejahteraan keluarga anggota kelompok usaha penghasil furniture dan penghasil kayu.
\end{abstract}

Kata Kunci : Pemberdayaan, Teknologi Produksi, Teknologi Pemasaran 


\section{PENDAHULUAN}

\section{Analisis Situasi}

Kabupaten Situbondo merupakan salah satu daerah yang ada di Provinsi Jawa Timur. Situbondo juga merupakan salah satu sentra UMKM penghasil produk-produk kerajinan (handycraft) yang saat ini juga menjadi penyumbang bagi PDB Nasional dan tercatat sebanyak 13.107 UMKM hingga tahun 2017 (Disperindag Situbondo 2017). Produk-produk tersebut diantaranya Merchandise, souvenir, furniture, anyaman dan surfing. Peluang bisnis tersebut sangat memiliki prospek yang baik kedepannya, terlihat dari banyaknya permintaan pasar pada produk ini. Data perdagangan elektronik (e-commerce) saat ini menepatkan produk kerajinan tangan berada pada posisi ketiga yang paling banyak diminati masyarakat. Tingginya persaingan membuat para pelaku bisnis UMKM ini dituntut untuk selalu melakukan inovasi-inovasi, baik dari segi desain tampilan, kualitas, harga maupun promosi.

Tingginya permintaan produk kerajinan tangan pada bisnis online tidak hanya merubah pola pemasaran yang sebelumnya dilakukan secara langsung (offline) menjadi berbasis internet (online). Perdagangan secara elektorik ini memberikan kemudahan akses bagi para konsumen dan konsumen untuk saling memenuhi permintaan dan permintaan produk, baik dari segi kemudahan mengakses sebuah produk maupun keamanannya. Pertumbuhan e-commerce di Indonesia saat ini sebesar 100-200\% per tahunnya (http://industri.bisnis.com). Pertumbuhan ini tentu berdampak terhadap berkembangnya bisnis jasa pengiriman, tingginya permintaan jasa pengiriman akan menciptakan persaingan bisnis sejenis untuk saling memberikan pelayanan yang maksimal. Seperti halnya pertumbuhan jasa pengiriman JNE, JNT dan Pos Indonesia mencapai 10-30\% setiap tahunnya.

Tingginya peluang bisnis tersebut berbanding terbalik dengan kondisi yang ada di Kabupaten Situbondo. UMKM pengasih kerajinan dihadapkan pada banyak permasalahan, salah satu diantaranya yaitu penerimaan teknology, baik dalam hal produksi maupun pemasarannya. Terpusatnya pasar penjualan produk kerajinan tangan mengakibatkan tingginya persaingan antar UMKM. Pasar yang masih 
tergantung pada pasar pengepul seperti di Provinsi Bali mengakibatkan harga tawar produk-produk tersebut menjadi sangat murah. Hal tersebut tentu akan berdampak langsung terhadap biaya produksi yang harus dikeluarkan. Akibatnya beberapa pelaku UMKM di Kabupaten Situbondo tidak bisa berkembang dan bahkan melakukan berbagai langkah untuk bisa menciptakan produk yang murah, salah satunya dengan persaingan bisnis yang tidak benar seperti halnya pencurian kayu Jati di hutan (illegal logging) marak terjadi hingga saat ini. Selain itu biaya tenaga kerja yang terus ditekan untuk bisa lebih murah, juga akan berdampak secara luas terhadap perekonomian masyarakat sekitar, dalam hal ini dari segi konsumsi. Pendapatan yang rendah juga akan menurunkan tingkat konsumsi masyarakat dan secara pertumbuhan perekonomian di Daerah akan mengalami perlambatan.

Rendahnya kreatifitas menjadi Permasalahan Utama, khususnya dalam hal proses produksi, dan pemasaran. Pemerintah tidak bisa dengan mudah memberikan langkah-langkah kebijakan tanpa adanya minat dan partisipasi sendiri oleh masyarakat sekitar untuk berubah dan berbaur dengan tekhnlogy. Minimnya kemampuan juga akan berakibat langsung terhadap prospek bisnis kedepan yang sulit menghadapi persaingan. Akibatnya minimnya kepercayaan perbankan dan investor untuk bisa memberikan investasi kepada pelaku UMKM tersebut. Oleh sebab itu melalui program ini

\section{Permasalahan Mitra}

Permasalahan yang ditemukan dan solusi yang ditawarkan :

a. Minimnya pengetahuan akan prinsip efisiensi dan efektifitas dalam produksi sebuah produk, Teknologi yang pemegang peranan penting untuk menciptakan produk berkualitas dan bernilai ekonomi tinggi. Teknologi produksi memegang peranan penting dalam menciptakan sebuah produk (kualitas, kuantitas, bentuk) serta harga jualnya

b. Kurangnya pemahaman dunia daring/online. Ketidakmampuan memahami dunia tekhnology dapat menghambat kemajuan usaha. Masyarakat cenderung memasarkan produk dengan bekerjasama pada pengepul produk seperti di Bali, menyebabkan nilai jual produk menjadi rendah dan berdampak pada 
keuntungan yang diperoleh. Rendahnya untuk membangun jaringan pemasaran dan kemampuan mencari pangsa pasar baru membuat para pelaku UMKM di Kabupaten Situbondo tidak bisa tumbuh secara signifikan

c. Kurangnya motivasi untuk membangun industri ke jenjang yang lebih maju. Hal ini diakibatkan tidak memahami manfaat dunia teknologi yang bisa merubah perjalanan bisnis menjadi lebih cepat dan mampu bersaing secara nasional maupun internasional.

\section{TARGET LUARAN}

Beberapa permasalahan yang dihadapi oleh kedua mitra program PKM selama ini diantara:

1. Minimnya pengetahuan akan prinsip efisiensi dan efektifitas dalam produksi sebuah produk, Teknologi yang pemegang peranan penting untuk menciptakan produk berkualitas dan bernilai ekonomi tinggi.

2. Kurangnya pemahaman dunia daring/online. Ketidakmampuan memahami dunia tekhnology dapat menghambat kemajuan usaha. Masyarakat cenderung memasarkan produk dengan bekerjasama pada pengepul produk seperti di Bali, menyebabkan nilai jual produk menjadi rendah dan berdampak pada keuntungan yang diperoleh.

3. Kurangnya motivasi untuk membangun industri ke jenjang yang lebih maju. Hal ini diakibatkan tidak memahami manfaat dunia teknologi yang bisa merubah perjalanan bisnis menjadi lebih cepat dan mampu bersaing secara nasional maupun internasional.

\section{Luaran}

Luaran program pengabdian ini diantaranya :

1. Menumbuhkan Jiwa wirausahaan yang maju dan berinovatif

2. Meningkatkan pengetahuan pentingnya tekhnologi dalam usaha pengolahan kayu menjadi produk furniture

3. Meningkatkan pengetahuan pemasaran online dengan media e-commerce sehingga meningkatkan pangsa pasar produknya 
4. Meningkatkan kesejahteraan keluarga anggota kelompok usaha penghasil furniture dan penghasil kayu

\section{METODE PELAKSANAAN}

Pelaksanaan kegiatan pelatihan dan pengembangan jiwa kewirausahaan serta penerapan teknologi produksi dan pemasaran yang berbasis digital pada Kelompok Usaha Furniture dan Penghasil Kayu Gmelina yaitu:

1. Pelatihan 1, Metode Penerapan Mesin Produksi

Kelompok usaha ini akan diberikan pemahaman bagaimana penggunaan mesin produksi berdasarkan jenis dan kegunaannya. Pemahaman ini dapat meningkatkan efisiensi proses produksi sebuah produk

2. Pelatihan 2, Pelatihan Teknis Pemotongan, Penghalusan, Dan Finishing Bimbingan secara teknis ini dapat membantu meningkatkan pemahaman bagaimana proses pemotongan, penghalusan, dan finishing yang benar sehingga menghasilkan produk yang terkualifikasi dan mampu bersaing dengan pabrikan.

3. Pelatihan 3, Pelatihan Pemasaran Berbasis Digital. Kunci keberhasilan industri adalah pada pemasarannya, apakah mampu menarik minat banyak konsumen sehingga pangsa pasar menjadi besar. Teknologi akan mendorong keberhasilan pemasaran dengan menggunakan media e-commerce

4. Evaluasi Hasil Pelatihan dan Pendampingan. Hasil pelatihan akan diberikan pendampingan dan evaluasi untuk mendukung program teknologi pada bisnisnya.

\section{HASIL DAN LUARAN YANG DICAPAI}

\section{Pendampingan Pengembangan Proses Produksi}

Pengembangan proses produksi untuk produk-produk furniture, harus didasari dengan perhitungan yang baik agar hasil produksi bisa ditekan dari segi biaya namun kualitas tetap terjaga. Tingginya persaingan bisnis furniture membuat para pelaku bisnis ini mulai bersaing dari segi harga, disamping dampaknya pada kualitasnya yang akan menurun pula. Perlunya langkah yang 
baik agar terciptanya produk yang berkualitas dan memiliki jangkauan pasar yang besar hingga ke seluruh negeri.

Untuk meningkatkan efektifitas dan efisiensi produksi dilakukan dengan langkah-langkah berikut :

1) Persiapan pemilihan Bahan baku kayu

Memilih bahan baku dilakukan untuk memastikan bahan baku kayu merupakan yang terbaik, pemilihan kayu yang salah mengakibatkan rendahnya kualitas furniture. Pemilihan harus disesuaikan dengan kebutuhan jenis dan ukuran kayu, terlalu besar akan menjadikan kayu terbuang sia-sia atau menjadi limbah. Saat ini kayu yang paling banyak tersedia dipasar yaitu gmelina, kayu ini sangat sesuai dengan produk furniture ini, karena teksturnya yang halus seperti kayu, daya tahan yang cukup awet seperti kayu jati.

2) Pemotongan Kayu

Tahap pemotongan menggunakan mesin slendang, jika dibandingkan dengan menggunakan mesin cyrcle akan lebih boros pembuangan sisa gergaji kayu yang dihasilkan. Menggunakan mesin slendang akan lebih lurus hasilnya namun kayu yang termakan oleh mata gergaji sangat kecil.

3) Tahap Pengeringan Kayu

Tahap pengeringan dapat dilakukan dengan tiga cara diantaranya :

a) Dijemur di bawah matahari

Penjemuran dengan sistem ini akan membuat kayu lebih lunak dikarenakan, proses pengeringan akan lebih cepat, namun harus dilakukan secara benar untuk menghindari pecahnya kayu akibat suhu terlalu panas.

b) Dimasukkan ke dalam Oven

Sistem ini dapat dilakukan sebagai pengganti matahari, namun penggunaan oven akan membuat biaya tambahan yang lebih besar, selain hasil pengeringan yang cepat namun masih lebih baik dilakukan dengan penjemuran matahari. 
c) Didiamkan di tempat yang kering

Pengeringan ini membutuhkan waktu yang cukup lama, namun dilihat dari segi kualitas, hasil pengeringan secara alami ini lebih baik untuk membuat struktur kayu lebih padat dan cara ini sangat baik untuk perusahaan furniture. Waktu pengeringan umumnya membutuhkan waktu empat bulan.

4) Persiapan Peralatan Produksi

Pemilihan alat produksi menjadi penting untuk memastikan setiap proses produksi akan menjadi lebih efektif dan efisien, beberapa peralatan yang dibutuhkan umumnya adalah :
a) Mesin Grinda pemotong
b) Mesin Grinda duduk
c) Mesin Grinda
d) Mesin Bor
e) Mesin Scroll Saw
f) Mesin Router
g) Mesin Serut
h) Kompressor

5) Modifikasi Alat Produksi

Modifikasi dilakukan agar penggunaan mesin bisa sesuai dengan kebutuhan proses produksi. Mesin dirancang agar bisa digunakan secara umum di lapangan, untuk menyesuaikan proses produksi perlu ditambahkan beberapa peralatan pelengkap diantaranya :

6) Pemetaan Bahan Baku Kayu

Pemetaan bahan kayu sebagai dasar untuk menentukan penggunaan bahan baku masing-masing, hal ini dilakukan untuk memanfaatkan kayu sesuai kebutuhan masing-masing jenis produk. Sebagi contoh untuk papan biasanya digunakan furniture hiasan dinding, dan kayu balok biasanya digunakan untuk meja. 
7) Proses Pemotongan, penghalusan dan Pengeleman

Proses pemotongan dilakukan dengan mesin pemotong kayu, menggunakan ukuran yang ditetapkan kemudian dilanjutkan dengan proses penghalusan menggunakan mesin serut kayu

8) Proses Finishing

Proses finishing harus dilakukan secara hati-hati untuk memastikan permukaan produk furniture menjadi halus tanpa pori-pori. Proses finishing umumnya dilakukan sebanyak 5 kali menggunakan media cat minyak maupun dengan cat dengan campuran air. Proses juga ditambah dengan

9) Packing Produk

Pacing merupakan tahap akhir setelah produk telah siap untuk dipasarkan, hasil produksi kemudian dimasukkan sesuai besaran packing yang tersedia. Setiap produk yang selesai wajib untuk dilakukan packing produk untuk memberikan identitas resmi bagi produknya dengan tambahan label produk.

\section{Pengembangan Pemasaran berbasis digital}

Pendampingan pengembangan pemasaran bagi kelompok usaha furniture juga diberikan untuk memastikan produknya bisa dipasarkan secara nasional. Melalui e-commerce Shopee, Bukalapak, dan Tokopedia. Perkembangan ecommerce indonesia didukung penuh oleh tingginya promosi yang dilakukan, menggunakan endorser, melalui media televisi maupun sosial media dan media cetak. Maraknya promosi yang dilakukan secara besar-besaran ini membuat pemahaman masyarakat tentang apa itu ecommerce menjadi tinggi. Didukung dengan adanya jaminan dan gratis biaya pengiriman, ketertarikan semakin tinggi untuk mencoba berbelanja online. Berkembangnya sektor dari sistem pembayaran digital perusahaan franchise seperti indomart, jasa perbankan yaitu e-banking menjadi dongkrak utama yang bisa memberikan kemudahan bertransaksi. Pembayaran produk yang dibeli kemudian dapat dilakukan dimana saja dan kapanpun, disamping itu juga jaminan-jaminan keamanan transaksi yang 
diberikan membuat perasaan khawatir untuk ditipu menjadi berkurang. Berikut model transaksi melalui e-commerce antara penjual dan pembeli :

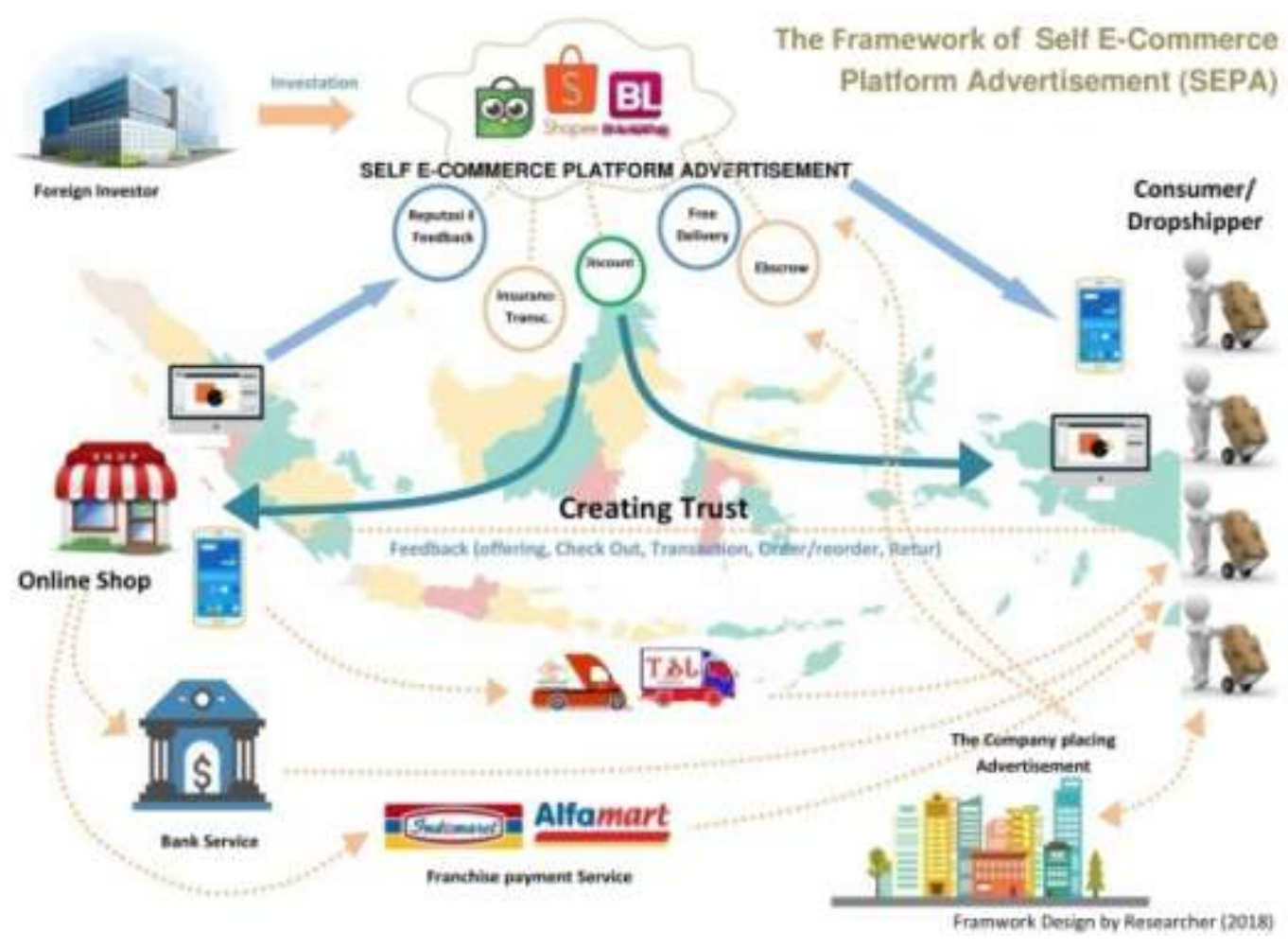

Gambar 1. Framework e-commerce

Manfaat yang bisa diambil oleh kelompok usaha ini tersebut dalam pemasaran diantaranya :

1. Model produk, yaitu bagaimana model suatu produk agar menarik perhatian konsumen untuk membelinya, hal yang terkandung dalam model ini termasuk bentuk furnitur yang inovatif menjadi beberapa macam bentuk terbaru atau berbeda dengan yang lainnya.

2. Harga jual produk, yaitu dengan menyesuaikan antara total biaya produksi dan laba yang direncanakan maka akan mengetahui harga jual produk yang sesungguhnya kemudian untuk menjadi pertimbangan apakah harga yang ditawarkan bisa bersaing di pasar atau tidak. Harga jual produk furniture hiasan dinding pada umumnya dikisaran Rp. 50.000 s.d Rp. 300.000,-

3. Promosi, yaitu langkah untuk memperkenalkan produk kepada masyarakat. Langkah pemanfaatan tekhnologi adalah yang paling tepat, media 
pemasaran online sangat membantu untuk mempercepat proses pemasaran produk. Beberapa cara pemasaran yang diajarkan diantaranya yaitu dengan media sosial facebook, Instagram, Whatsapp. Sedangkan media untuk bertransaksi, anggota PKK diberikan pemahaman membuka toko online di Bukalapak, tokopedia dan shopee.

4. Distribusi, yaitu bagaimana membuat produk bisa sampai pada konsumen, penjualan bisa dengan cara direct selling atau penjualan langsung dan bisa juga dengan agen. Langkah-langkah pengenalan produk dengan cara langsung tersebut merupakan hal yang paling mudah untuk dilaksanakan bagi usaha-usaha di masyarakat yang kemudian akan semakin dikenal dan diminati oleh masyarakat banyak. Jika menggunakan media penjualan online maka jasa pengiriman dibutuhkan seperti JNE, J\&T dan Pos Indonesia.

\section{Pendampingan Manajemen Keuangan}

Materi yang diberikan yaitu mengenai pengelolaan manajemen usaha mikro yaitu proses produksi dan keuangan, permasalahan yang sering terjadi bagi usahausaha kecil yang dimasyarakat juga menjadi pembahasan dalam pelatihan ini sebagai pedoman untuk meningkatkan jumlah wirausaha baru dan peningkatan pendapatan. Kegiatan ini diharapkan mampu untuk meningkatkan penjualan makanan pizza di Kabupaten Situbondo sehingga bisa meningkatkan pendapatan keluarga dan menjadi industri rumah tangga yang handal dan dapat terus dikembangkan. Materi keuangan diarahkan untuk mengetahui tentang sumber permodalan usaha serta seberapa besar permodalan yang dibutuhkan untuk usaha tersebut, setelah mengetahui prosesnya maka diharapkan mampu untuk memulai manajemen usaha yang mandiri serta mampu mencatat keuangannya dari segi besar biaya dan pendapatan yang diperoleh untuk mengetahui apakah usahanya akan untung maupun rugi.

\section{Pendampingan tentang Hukum Bisnis}

Pelatihan tahap ini materi yang diberikan tentang pemasaran usaha dan bentuk-bentuk badan hukum serta persyaratan-persyaratan untuk pendiriannya. Untuk usaha perorangan bisa melakukan perijinan meskipun belum berbadan 
hukum UD atau PT. Oleh sebab itu melalui pelatihan ini diharapkan bisa meningkatkan kedisiplinan untuk mentaati peraturan tentang industri rumah tangga.

\section{Evaluasi Kegiatan}

Kegiatan evaluasi dilaksanakan sebagai monitoring atas hasil yang dicapai atas beberapa kegiatan sebelumnya apakah terdapat kendala yang dihadapi masing-masing peserta dalam melaksanakan proses produksi hingga pemasarannya. Kegiatan evaluasi ini sangat bermanfaat untuk mengukur kemampuan masing-masing peserta pengabdian dalam menyerap sehingga mempermudah proses pendampingan pada tahap berikutnya.

\section{Luaran Yang Dicapai}

Berikut luaran yang telah dicapai atas Program Kemitraan Masyarakat (PKM) ini yaitu :

a) Menumbuhkan Jiwa wirausahaan yang maju dan berinovatif.

Inovasi menjadi penting agar mampu bertahan di era persaingan saat ini yang sangat cepat, jika mampu menyesuaikan makan akan bertahan dan tetap maju bisnisnya.

b) Meningkatkan pengetahuan pentingnya tekhnologi dalam usaha pengolahan kayu menjadi produk furniture

Tekhnologi menjadi penting karena indonesia saat ini telah memasuki revolusi industri 4.0, stimulus pemahaman perdagangan digital perlu dilakukan untuk menopang tingginya transaksi berbasis daring.

c) Meningkatkan pengetahuan pemasaran online dengan media e-commerce sehingga meningkatkan pangsa pasar produknya

Penjualan online sudah menjadi trend saat ini, untuk itu seluruh anggota kelompok usaha ini telah memiliki kesiapan dan mampu untuk memasarkan produknya melalui e-commerce.

d) Meningkatkan kesejahteraan keluarga anggota kelompok usaha penghasil furniture dan penghasil kayu 
Dengan meningkatnya jaringan pemasaran melalui jaringan internet diharapkan nantinya akan berdampak terhadap perekonomian para pelaku industri tersebut

\section{KESIMPULAN DAN SARAN}

\section{Kesimpulan}

Kegiatan ini merupakan pembinaan dalam bentuk perbaruan metode produksi dan pemasaran dengan langkah yang lebih efektif dan efisien. Minimnya pengetahuan para pelaku usaha untuk bisa menghasilkan produk berkualitas. Pembinaan ini dilakukan dengan melalui metode Penerapan Mesin Produksi, Pelatihan Teknis Pemotongan, Penghalusan, Dan Finishing, Pelatihan Pemasaran Berbasis Digital dan Pendampingan akhir. Luaran yang dihasilkan dari kegiatan ini adalah Menumbuhkan Jiwa wirausahaan yang maju dan berinovatif, Meningkatkan pengetahuan pentingnya tekhnologi dalam usaha pengolahan kayu menjadi produk furniture, Meningkatkan pengetahuan pemasaran online dengan media e-commerce sehingga meningkatkan pangsa pasar produknya, Meningkatkan kesejahteraan keluarga anggota kelompok usaha penghasil furniture dan penghasil kayu.

\section{Saran}

Saran yang bisa diberikan atas pelaksanaan Program Kemitraan Masyarakat (PKM) kepada kedua mitra yaitu :

1. Perlunya niat dan semangat untuk memulai usaha dan mengembangkannya khususnya produk furniture ini agar program peningkatan jiwa wirausaha menjadi terwujud dengan baik dan bisa menularkan pada anggota lainnya.

2. Untuk bisa mewujudkan menjadi seorang wirausahawan sejati, diperlukan kedisiplinan dan fleksibilitas dalam hal ide baru agar produk-produk yang dihasilkan mampu bersaing di pasar. 


\section{DAFTAR PUSTAKA}

Abdullah, Maskur. 2005. Lilitan Masalah Usaha Mikro kecil, Menengah (UMKM) dan Kontroversi Kebijakan. Medan: Bitra Indonesia.

Anoraga, Panji. 2002. Koperasi, Kewirausahaan, dan Usaha Kecil. Jakarta: Rineka Cipta.

Departemen Perdagangan Republik Indonesia. 2008. Pengembangan Ekonomi Kreatif Indonesia 2025: Rencana Pengembangan Ekonomi Kreatif Indonesia 2009-2025. Jakarta: Departemen Perdagangan

Fuady, Munir, Pengantar Hukum Bisnis, (Bandung : PT.Citra Aditya Bakti, cetakan ke II, 2005)

Kotler, Philip, 2002, Manajemen Pemasaran, Jilid 2, Alih Bahasa oleh Hendra Teguh dkk, Edisi Milenium, Jakarta : PT Prenhallindo

Miftahus Sholihin, Siti Mujilahwati (2016), Dampak Pemanfaatan E-Commerce Terhadap Peningkatan Penjualan Di UMKM : Jurnal Teknika Vol. 8 No. 1 Maret 2016

Diyan Ivanov (2012) The impact of e-commerce on small-size companies in Swede : Karistad University : swedan

A Industri, Tokopedia.com Catat Pertumbuhan Transaksi 200\%. Diakses pada tangal 17 Desember 2017. http://industri.bisnis.com, E-COMMERCE:

Ann L. Fruhling, Lester A. Digman (2000) The Impact Of Electronic Commerce On Business-Level Strategies : Journal of Electronic Commerce Research, VOL. 1, NO. 1, 2000 